\title{
Context matters: influence of organizational, environmental, and social factors on civic environmental stewardship group intensity
}

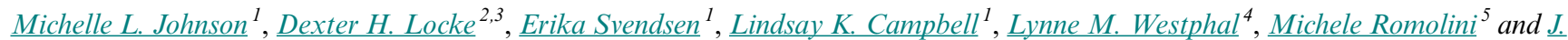 \\ Morgan Grove $^{3}$
}

\begin{abstract}
Civic environmental stewardship groups actively take care of their local environment and are known to work in urban contexts. Research on the geographies of this urban environmental stewardship is young. Understanding where stewardship groups work and the associated organizational and neighborhood contexts advances the understanding of the environmental outcomes of stewardship efforts. We examine the organizational, socioeconomic, and environmental contexts associated with the number of stewardship groups at the Census block group and neighborhood scales for four diverse U.S. cities (Baltimore, MD; Chicago, IL; New York, NY; and Seattle, WA). We found relatively consistent and strong relationships with both average professionalization (staff and budget index) and diversity of groups' focus and the number of groups' activity areas in a block group or neighborhood, suggesting a potential density dependence effect. Overall, the number of stewardship groups correlates with social and environmental aspects at both scales across all cities, but variation across cities for specific variables indicates the need for further analyses to unpack why we observe these different patterns across cities. Strong relationships with organizational factors suggest future directions for stewardship research and that the organizational landscape may affect how many groups work in a place more than socioeconomic or environmental conditions.
\end{abstract}

Key Words: civic stewardship; collaboration; environmental justice; social-environmental; spatial analysis; urban ecology

Context matters: influence of organizational, environmental, and social factors on civic environmental stewardship group intensity

\section{INTRODUCTION}

Civic environmental stewardship groups actively conserve, manage, monitor, transform, advocate for, and educate those in their communities about their local environment, including land, air, water, toxics, and energy issues (Fisher et al. 2012, Campbell et al. in press). Such groups in U.S. cities can be incredibly diverse in their mission, age (Svendsen and Campbell 2008), and degree of professionalization (Fisher et al. 2012). Some stewardship groups play a critical role in bridging otherwise disparate communities with environmental concerns across government, business, and civil society sectors (Connolly et al. 2013, 2014). This bridging role can both improve and constrain ecosystem management (Ernstson et al. 2008). Evidence from New York City (NYC) demonstrates civic environmental stewardship group activities may be associated with land use and cover change (Locke et al. 2014), suggesting stewardship groups can impact the quantity and quality of urban ecosystem services (Andersson et al. 2014). Knowing more about the geographies of civic stewardship may suggest critical patterns and processes occurring within cities. Stewardship often directly touches down in space, in specific locations, making a subcity unit like the neighborhood an appropriate unit of analysis. Through interview-based research, Connolly and colleagues (2014) have shown NYC environmental stewardship networks to be organized by geography as well as function, e.g., type of stewardship actions and behavior. However, it is not known which factors explain the proliferation or dearth of groups in a particular location: organizational, socioeconomic, and/or environmental conditions.
Despite the inherently socio-spatial nature of these groups and their activities, the geographies of civic environmental stewardship in cities remain understudied. Understanding what explains the abundance of groups in a neighborhood can help us understand how inequities in civic stewardship capacity are created, maintained, and potentially altered through strategic interventions.

Studies across cities or across neighborhoods can identify general patterns that transcend a single spatial unit (Sampson 2008). Nascent research on the geographies of stewardship has begun to indicate that urban environmental stewardship groups vary in their spatial extent (Romolini et al. 2013). Uneven distribution of stewardship raises questions about allocation of government resources and civic capacity in neighborhoods across a city. Understanding where stewardship groups work and the neighborhood context has implications for potential environmental outcomes of civic stewardship, through enabling care, research, and monitoring of specific places. Examining the geographies of urban environmental stewardship may also inform theory about human-environment interactions and innovations, which is important as urban populations continue to rise and critical demands on resources are made (Locke and McPhearson 2018, Sanderson et al. 2018). Finally, an exploration of where groups work may help identify where within cities opportunities for stewardship investment and organizing are most needed and where other types of environmental management can complement ongoing civic efforts.

In this paper, we ask: What are the neighborhood-level organizational, socioeconomic, and environmental characteristics

${ }^{1}$ USDA Forest Service, Northern Research Station, NYC Urban Field Station, Bayside, NY, USA, ${ }^{2}$ National Social-Environmental Synthesis Center (SESYNC), Annapolis, MD, USA, ${ }^{3}$ USDA Forest Service, Northern Research Station, Baltimore Field Station, Baltimore, MD, USA, ${ }^{4}$ USDA Forest Service, Northern Research Station, Evanston, IL, USA, ${ }^{5}$ Center for Urban Resilience, Loyola Marymount University, Los Angeles, CA, USA 
associated with urban environmental stewardship? We examine stewardship activity areas, i.e., where groups work, in Baltimore, MD; Chicago, IL; New York, NY; and Seattle, WA. We explore whether the amount of groups engaging in civic environmental stewardship activity is consistently related to these variables across the four cities and at two geographic scales. We define a stewardship activity area as a self-described spatial area of activity where a group is engaging in environmental stewardship.

\section{Background}

\section{Civic and environmental participation}

In addition to taking care of the environment, stewardship is a form of civic engagement. Civic environmental stewardship groups typically comprise volunteers; some have formal members and paid staff. Stewardship groups heavily rely on members of the general public and key organizational partners to function. Cities with the highest civic participation have a strong corporate presence, more public spaces, a healthy community identity, good government, youth investment, and means of mobilization (Engbers 2016). In previous studies on civic engagement, population size has been related to civic activities. Larger cities have lower levels of public engagement in contacting officials, participating in meetings, and voting and larger numbers of voluntary organizations (Tavares and Carr 2013). However, city size is mediated by population density and growth rates, whereby higher population densities depress the effect of city size on voting and amplify the number of voluntary organizations, while increased population growth rates depresses the effect of city size on voluntary organizations (Tavares and Carr 2013).

\section{Organizational characteristics of civic organizations}

Characteristics of organizations themselves also have the potential to influence where groups work, and, thus, the stewardship capacity of a neighborhood. Organization age, tax status, and staff size can speak to an organization's level of formalization, resources, and degree of professionalization (Hwang and Powell 2009, Fisher et al. 2012). These characteristics can influence the group's capacity, which may affect where and in how large of an area groups work. Density dependence, an ecological concept, has been incorporated into organizational theory to understand how many organizations can occur in a given location (Hannan and Freeman 1989), finding the rates of founding and mortality of organizations in a population to be positively related to the number of organizations in the population.

Collaboration and competition between groups also has the potential to affect the number of groups working in a single location. Much work has focused on socio-spatial aspects of social movements (Nicholls 2009), but the physical nature of the city landscape may also create opportunities and barriers for collaboration between civic environmental groups sharing the same space. Spatial distance between two organizations can affect the probability of groups working together (Illenberger et al. 2013). In New Orleans, Cape Town, and Phoenix, Ernstson et al. (2010) observe nearby organizations with a similar focus are more likely to collaborate with each other than other organizations. Competition among civic organizations occurs simultaneously, which can limit neighborly collaboration. In Baltimore, neighborhood associations are prevalent and often stake out small territories; the proliferation of community groups with a similar focus has occurred as a result of competition (Meyer and Hyde 2004).
Socioeconomic conditions at the neighborhood scale

Civic participation also varies within cities and is, in part, linked to variation in socioeconomic conditions of neighborhoods. When neighborhood poverty is controlled for, participation in voluntary association varies by race, with African-Americans participating more than Whites and other racial groups (Stoll 2001). Other studies have found higher participation in more homogeneous societies, in terms of racial and income diversity (Costa and Kahn 2003, Tolsma et al. 2009, Rotolo and Wilson 2014). Homeowners, regardless of home value or time in neighborhood, are more likely to volunteer than renters and tend to be more attached to their neighborhood, as are long-term residents (Rotolo et al. 2010). At the individual level, higher education levels are also associated with higher levels of volunteerism (Wilson 2012).

Specifically for organizational stewardship research, Romolini et al. (2016) point to the need to analyze stewardship networks through a spatial lens. Indeed, at the neighborhood scale with spatial regressions, Romolini et al. (2013) found relationships between the number, diversity, and connectedness of environmental stewardship groups and the percent of White residents in Baltimore, but not in Seattle.

\section{Local environmental conditions}

Urban greenspace is typically managed at the local scale, with a focus on managing a single site's characteristics, versus managing across a network of sites (Andersson et al. 2007, 2014). Environmental features such as parks and open space in cities are known to vary in distribution and quality across space. Access to parks and greenspace is often considered an environmental justice issue (Boone et al. 2009). For example, tree canopy cover varies by socioeconomic characteristics such as race, education, home value, and household income across many cities at the Census block group scale (Landry and Chakraborty 2009, Schwarz et al. 2015, Gerrish and Watkins 2018, Watkins and Gerrish 2018). Sampson (2017) points to the combination of racial and economic segregation as a core social feature of spatial inequality in American cities, and links these with environmental degradation. Political ecologists also have pointed to such inequities in urban society and its implications for the uneven distribution of ecological resources (Heynen 2003, Walker 2009).

Linkages between civic environmental stewardship groups and neighborhood conditions remain understudied, despite the importance of understanding civil society's role in the dynamics of maintaining and transforming nature in cities. For example, Andersson et al. (2014) identified the need to understand the connection between stewardship and changes in biodiversity and ecosystem services. However, some aspects of group intent and action have been researched, finding variation in which places within cities are focused on by groups. Romolini et al. (2013) suggested the potential for differences between groups taking care of green space (e.g., conservation) and brown spaces, like brownfields (e.g., restoration) in cities; this typology was also identified by qualitative interviews of stewardship groups in NYC (Connolly et al. 2013, Locke et al. 2014). Similarly, in Sweden, stewardship groups collaborate based primarily upon site type, with less coordination among neighboring groups (Borgström et al. 2006, Ernstson et al. 2010). In Chicago, stewardship groups were located in rich and poor neighborhoods, and in neighborhoods of different races and ethnicities (Westphal et al. 2014). 


\section{METHODS}

\section{Study area cities: an overview}

This paper's four U.S. study cities are: Baltimore (established 1729), Chicago (established 1833), New York City (established 1624), and Seattle (established 1851; Table 1). We selected these cities because of their available civic stewardship group data with the Stewardship Mapping and Assessment Project (STEWMAP). The population dynamics of these cities have varied over time, with Baltimore's population continuing a "steady decline," Chicago's being "slowly resurgent," and New York City and Seattle having "growth interrupted" (Short and Mussman 2014). We do not include a city from Short and Mussman's "continuous increase" category, which predominantly includes cities in the south and western portions of the United States, because of lack of available data. In relation to these population trends, the study area cities have differing land use forms. Increased demand for housing is reducing vacancy rates in Chicago, Seattle, and New York (Mallach 2018), although the amount and/or number of vacant lots can still be high in these cities (Kremer et al. 2013). Baltimore continues to have high vacancy rates, but is also actively converting vacant lots into parks and community gardens as part of city programs (Mallach 2018). Each city also has its unique history of greenspace and development, which has affected the spatial distribution, amount, and size of parklands, community gardens, and other open space. For example, the housing market in New York City limits the increase in community gardens, while Baltimore is actively encouraging community gardens through the Adopt-a-Lot program. Also, in the development of these cities over time, U.S.-wide movements such as City Beautiful (circa 1890s-1990s) have influenced the design of at least some parks in the study area cities (Wilson 1994).

Intertwined with greenspace establishment and development trajectories is the governance structure of greenspace in each city. At the time of the Chicago STEW-MAP survey, Chicago Wilderness was an over-arching alliance of 247 organizations engaged in voluntary stewardship in the greater Chicago region (Chicago Regional Biodiversity Council 1999). New York City, Baltimore, and Seattle, all coastal cities, contain public-private partnerships focused on coordinating water and waterfront management through EPA-initiated estuary partnerships (Harbor and Estuary Program in NYC, the Chesapeake Bay Program in Baltimore, and the Puget Sound Partnership in Seattle). Additionally, there are specific types of governance structures more prominent in some cities than others. Beginning with the Central Park Conservancy in the 1980s, New York City has promulgated the park conservancy model of public-private partnerships for many individual parks in the city. Finally, in each city, the local government's management of green spaces can be centralized or decentralized: in Baltimore, Baltimore Recreation and Parks manages parks, both Baltimore Recreation and Parks and Baltimore Housing manage some of the city's community gardens, and street trees are managed by TreeBaltimore (a municipal government program) with support from local community groups; in Chicago, Chicago Parks District manages parks and some community gardens, while the Bureau of Forestry manages street trees; in New York City, the Department of Parks and Recreation manages street trees, parks, and gardens; in Seattle, Seattle Neighborhoods manages the community garden program, Seattle Parks and Recreation manages parks, and Seattle Department of Transportation manages street trees.

\section{Data}

Number of civic environmental stewardship groups

We compiled STEW-MAP survey data from our four study area cities, all of which participated in the Stewardship Mapping and Assessment Project (STEW-MAP) within a five-year time period (Table 1, Fig. 1). This survey collected data on stewardship groups in three domains: group characteristics, stewardship networks, and geographies of stewardship (Svendsen et al. 2016). For Baltimore, NYC, and Seattle, a population sampling frame of nonprofit organizations and community groups that may engage in environmental stewardship was developed by consolidating multiple lists of potential stewardship groups, from local partners' contact lists and registered IRS datasets. These sampling frames were designed to include civic organizations beyond solely environmental groups who also engage in environmental stewardship. As such, the sampling frames include community development organizations, youth groups, churches, and many other civic organizations where the main organizational focus is not the environment (Svendsen et al. 2016). This method results in a sampling frame representing the core network of civic environmental stewardship groups connected to the citywide environment and natural resource management community (see Fisher et al. 2012, Svendsen et al. 2016). In Chicago, a combination of a sampling frame and an open, crowd-sourced survey was applied. Given the difference in sampling method, we have interpreted results comparing Chicago with the other three

Fig. 1. Number of stewardship groups by study area city, at the Census block group scale.

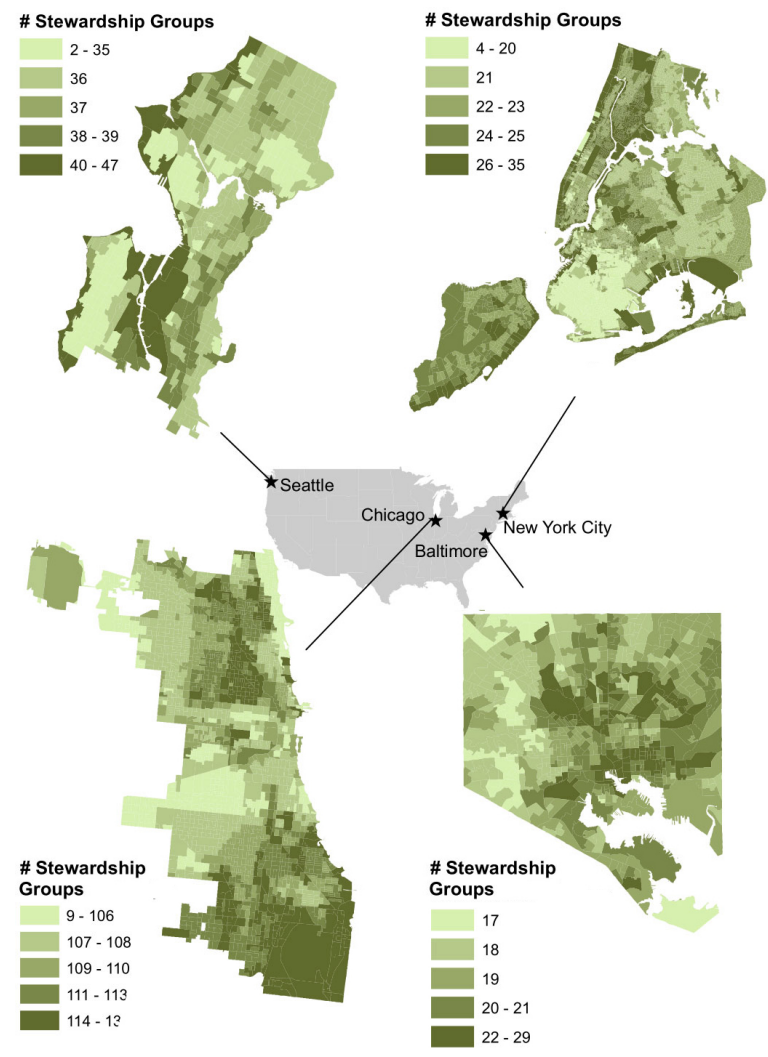


Table 1. Socioeconomic and environmental characteristics of cities included within the four study areas. Citywide totals on top with Census block group (CBG) means, standard deviation (s.d.), and Moran's I below.

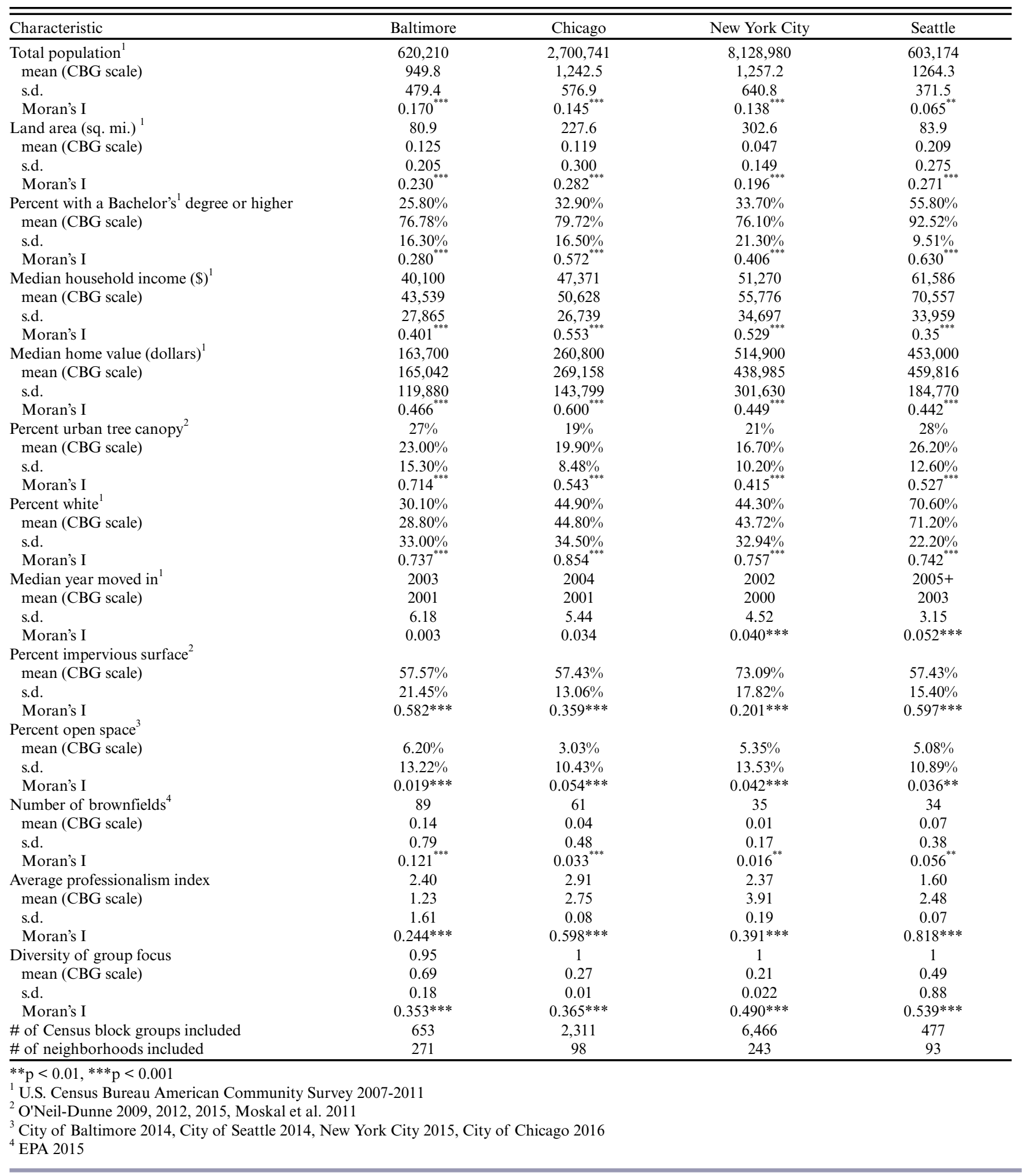


Table 2. Stewardship Mapping and Assessment Project (STEW-MAP) survey and activity area attributes by study area city.

\begin{tabular}{|c|c|c|c|c|}
\hline Characteristic & Baltimore & Chicago & New York City & Seattle \\
\hline STEW-MAP survey year & $2009-2010$ & 2010-2013 & 2007 & 2011 \\
\hline Civic survey respondents/response rate & $163(26.9 \%)$ & 296 (Not available ${ }^{\dagger}$ ) & $506(18.3 \%)$ & $144(25.4 \%)$ \\
\hline Number of civic groups in city (sampling frame) & 692 & Not available ${ }^{\dagger}$ & 2517 & 604 \\
\hline Number of civic group stewardship turfs in analysis & 132 & 231 & 495 & 112 \\
\hline Number turfs/Census block group (mean, s.d.) & $19.33(1.81)$ & $42.42(2.87)$ & $22.11(2.36)$ & $38.5(3.02)$ \\
\hline Number turfs/neighborhood (mean, s.d.) & $20.37(2.60)$ & $117.43(8.47)$ & $27.55(5.29)$ & $38.51(3.07)$ \\
\hline Proportion of turfs covering entire city & $2.60 \%$ & $62.77 \%$ & $0.38 \%$ & $34.42 \%$ \\
\hline Global Moran's I-Census block group * & 0.42 & 0.76 & 0.64 & 0.25 \\
\hline Global Moran's I-neighborhood ${ }^{*}$ & 0.45 & 0.51 & 0.48 & 0.25 \\
\hline
\end{tabular}

${ }^{\dagger}$ The STEW-MAP Chicago project used a mixed-methods approach en lieu of developing a population sampling frame.

*All Moran's I values significant at $\alpha=0.05$.

cities conservatively. Previously published STEW-MAP survey response rates are within the range of organizational studies (Hager et al. 2003; Table 2). A response rate is unavailable for the full Chicago dataset, although a subset of Chicago Wilderness members had a 49\% response rate (Westphal et al. 2014).

On the STEW-MAP survey, groups were asked where they physically work, enabling construction of polygons in a Geographic Information System (GIS) which reflect groups' activity areas, or spatial footprints (Wolf et al. 2013). This is similar to how activity-space is defined and analyzed for individuals (Baek et al. 2015). Respondents provided a description or boundary polygon of where they worked, which we then mapped in ArcGIS 10.1 (ESRI 2012) and linked to survey responses (Svendsen et al. 2016). To standardize across cities, we included only civic groups operating within city boundaries. For each group's area of activity, boundaries were dissolved to the maximum extent, so that each group would only be captured once when aggregating areas of activity to Census block group and neighborhood scales.

We assessed survey responses for spatial representativeness in NYC and Seattle by comparing the spatial distribution of office locations and/or contact addresses for respondents and nonrespondents using the cross $\mathrm{L}$ function (a variation of a bivariate Ripley's K). We selected office locations as the variable for analyzing spatial representativeness because a group's area of activity was only available for groups that responded to the STEW-MAP survey. We used the spatstat package in $\mathrm{R}$ 3.4.1 (Baddeley and Turner 2005, R Core Team 2017). This method identifies whether the two point patterns are spatially clustered together, are dispersed with respect to each other, or have no statistically significant spatial relationship. For Baltimore, we lacked the spatial data for the full survey sampling frame, and, for Chicago, a combined approach of sampling frame and open survey was applied for the survey, which limited this type of analysis.

\section{Independent variables at Census block group and neighborhood} scales

We compiled datasets in ArcGIS 10.1 (ESRI 2012) for each city at the Census block group scale. We selected the 2007-2011 American Community Survey (ACS) TIGER feature classes for block groups in each city to align with STEW-MAP survey timing (Table 2). We hypothesized relationships between neighborhood- level correlates of stewardship groups' activity across geographic space, drawing upon research on organizational characteristics, neighborhood-level volunteerism, and socioeconomic relationships with greenspace (Table 3). Average professionalization index was calculated at the Census block group level by averaging all groups' professionalization index (1-5 index of staff and budget) with areas of activity that overlapped the Census block group. We hypothesized group professionalization may affect how many groups work in a given area, because groups with more staff and budget, i.e., higher professionalization, have more resources with which to engage in stewardship. Diversity of groups' focus was calculated at the Census block group level by summing the different types of group foci in each area, e.g., youth, environment, community development; individual groups could identify multiple foci from a set list. Thus, Census block groups with a higher count of different foci of civic groups result in higher numbers of diversity of groups' focus. We hypothesized diversity of groups' focus in a neighborhood could be associated with the number of groups working there, but we did not hypothesize the direction of this relationship, because of conflicting reasons for competition and collaboration. Groups with similar missions have incentives to collaborate to share labor, cowrite grants, and share knowledge, but they also have incentives to compete for funding when resources are limited (Staggenborg 1986). Because education, income, ethnicity, and racial homogeneity have been shown to influence individual volunteerism, we hypothesized these variables may be associated with a greater number of stewardship groups. We also hypothesized amount of greenspace available to steward is positively associated with number of stewardship groups, including measures of open space, overall tree canopy, and, inversely, impervious surface. Lacking a consistent measure for vacant lots across the four cities, we excluded this variable from analysis. Finally, we hypothesized presence of brownfields would be positively correlated with the abundance of stewardship activity areas, building upon previous qualitative research in NYC (Connolly et al. 2013, Locke et al. 2014). We included population density as a control variable.

To evaluate the sensitivity of our results to the choice of spatial scale, we conducted a parallel set of analyses at a larger neighborhood scale, applying neighborhood polygon boundaries obtained from cities' respective departments of planning (Table 2 ). Block group attributes were aggregated to neighborhood boundaries using an area-weighted reaggregation process (Reibel 
Table 3. Predictor variables used in Poisson and spatial regressions. ACS, American Community Survey; STEW-MAP, Stewardship Mapping and Assessment Project.

\begin{tabular}{ll}
\hline \hline Variable & Source \\
\hline $\begin{array}{l}\text { Socioeconomic variables } \\
\text { Population density }\end{array}$ & ACS 2007-2011, ACS 2007-2011 TIGER geodatabase (all \\
& cities) \\
Median household income & ACS 2007-2011 (all cities) \\
Median home value & ACS 2007-2011 (all cities) \\
Percent of population with a Bachelor's or greater & ACS 2007-2011 (all cities) \\
$\begin{array}{l}\text { Percent white only } \\
\text { Median year moved }\end{array}$ & ACS 2007-2011 (all cities) \\
Environmental variables & ACS 2007-2011 (all cities) \\
Urban tree canopy & \\
Impervious surface & O'Neil-Dunne 2009, 2012, 2015, Moskal et al. 2011 ${ }^{1}$ \\
Percent open space & O'Neil-Dunne 2009, 2012, 2015, Moskal et al. 2011 \\
Brownfield ${ }^{\dagger}$ & Cities' parks and open space GIS datasets ${ }^{2}$ \\
Organizational variables & EPA 2015 (all cities) \\
Professionalization index (average) & \\
Diversity of group focus & STEW-MAP datasets \\
\hline $\begin{array}{l}\text { No brownfield is the base case } \\
\text { Baltimore - 2007 imagery, Chicago - 2010 imagery, New York City - 2010 imagery, Seattle - 2009 imagery. }\end{array}$ & STEW-MAP datasets \\
\hline City of Baltimore 2014, City of Seattle 2014, New York City 2015, City of Chicago 2016.
\end{tabular}

2007), resulting in a parallel set of datasets with larger, but fewer polygons containing the same variables.

\section{Statistical analyses}

To investigate correlations between number of civic environmental stewardship groups' areas of activity and organizational, socioeconomic, and environmental variables, we fit count-based regression models, with the unit of analysis at the Census block group level. We ran bidirectional stepwise Poisson models, using an AIC minimization technique in the MASS package in $\mathrm{R}$ to find more parsimonious models (Venables and Ripley 2002). The model with the lowest AIC value was then fit as a negative binomial model. Using a likelihood ratio test, we compared Poisson and negative binomial models, and retained the more appropriate model.

We also fit spatial models with the same variables, to produce narrower confidence intervals and to explicitly incorporate the spatiality of the data, after detecting significant spatial autocorrelation in residuals of the Poisson and negative binomial models. All spatial error and lag models were run using the spdep package in R (Bivand and Piras 2015). For each city, we applied the Lagrange multiplier test to select a lag or error specification (Anselin 2005). To assess the potential effects of multicollinearity, we calculated Variance Inflation Factors (VIFs) for all cities' Poisson models. VIFs for all models were all below 3.00, indicating low concerns for multicollinearity (Marquardt 1970). Spatial error models were selected for all cities, except a spatial lag model for Chicago at the neighborhood scale. We then calculated marginal effects as a percentage, per Troy et al. (2016), to enable an equivalent comparison between the retained Poisson and spatial lag/error models within each city.

As a robustness check, we refit retained Poisson and spatial models at the neighborhood level, to address concerns over the Modifiable Areal Unit Problem (or MAUP; Openshaw 1984). We then qualitatively compared neighborhood-scale models with the finer scale Census block group models.

\section{RESULTS}

\section{Representativeness of spatial data}

We examined the representativeness of the spatial distribution of respondent office locations as compared to nonrespondent office locations for NYC and Seattle by running 10,000 simulations of the $\mathrm{L}$ cross function. We observed no statistical difference in the spatial distribution of respondent addresses as compared to nonrespondent addresses (Appendix 1). We did not conduct this analysis for Baltimore or Chicago, so cannot draw generalizable conclusions for those cities' stewardship groups.

\section{Statistical models}

Overall, $\mathrm{R}^{2}$ values indicate neighborhood-scale models explained more variation for Poisson models (Table 4), while Census block group-scale models explained more variation for spatial models (Table 5). The best fit models for Baltimore, Chicago, and NYC were the Census block group spatial lag and/or error models, while the neighborhood-level spatial error model was the best fit model for Seattle. Overall, the Seattle models were a poorer fit than for the other three cities.

Coefficients for Poisson models are presented as odds ratios in Table 4, with a number greater than one indicating a positive association on the dependent variable and a number less than one indicating a negative association. To enable a comparison of effects across the Poisson and spatial models, we present a marginal effects table, calculated as the percent change in the dependent variable (number of groups) as a result of a one-unit change in the independent variable for continuous variables and a categorical change for categorical variables (Table 6).

Across the four cities, different predictor variables were retained through the stepwise selection process, and, in some cases, different relationships for individual predictor variables emerged. This result was more prevalent for socioeconomic and environmental variables. In contrast, organizational variables had strong, relatively consistent relationships with number of groups. Across all cities, average professionalization index was inversely 
Table 4. Stepwise Poisson odds ratios (and 95\% confidence intervals) by study area city at Census block group (CBG) and neighborhood scales. Starred terms are significant (alpha $=5 \%$ ).

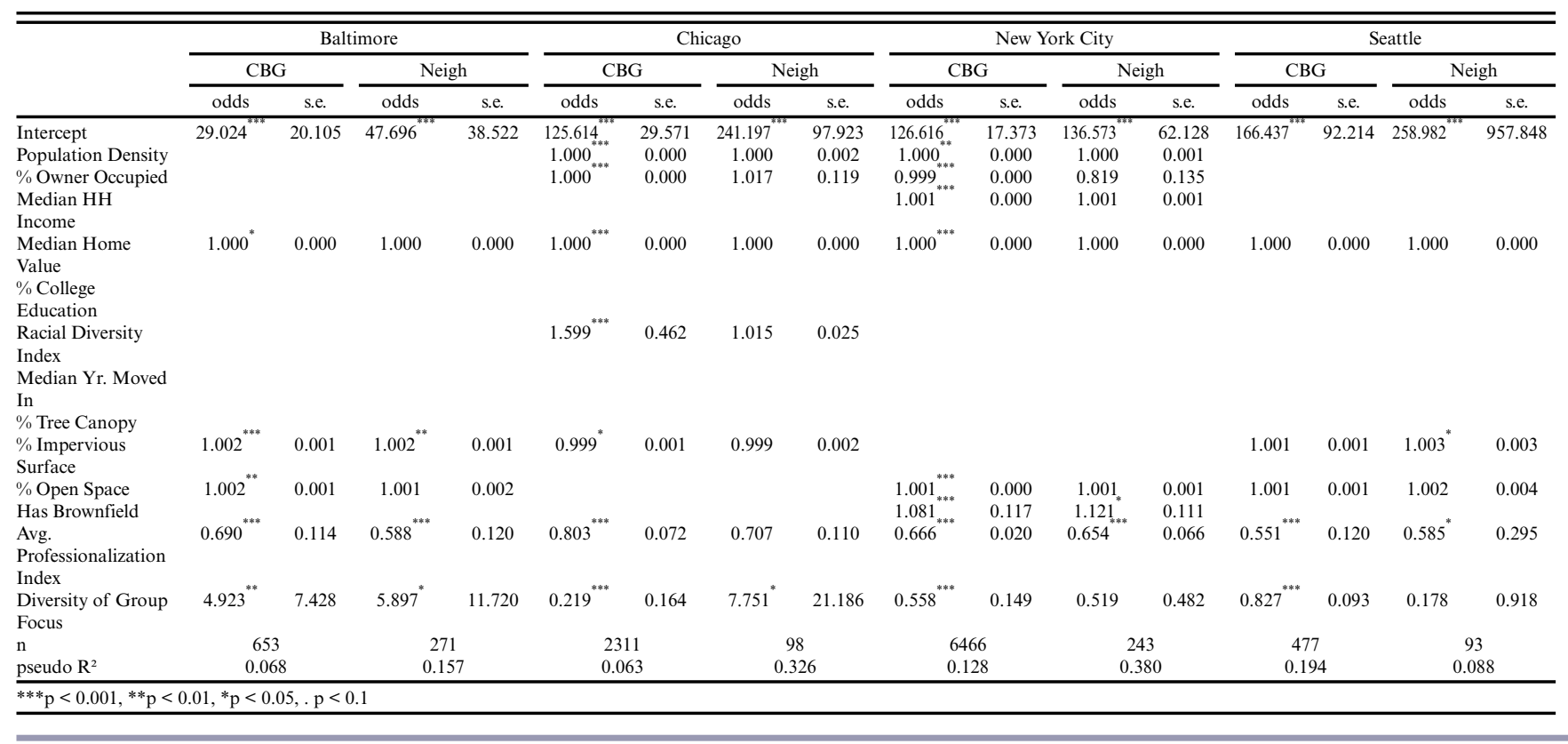

related to number of groups; the more professionalized the groups, on average, the fewer the number of groups in a block group or neighborhood. Diversity of group focus was inversely related to the number of groups, except for all Baltimore models and Chicago's neighborhood-level Poisson model.

Results varied across cities for other independent variables. For example, population density is a significant factor for Chicago and Seattle, but not Baltimore and NYC. Higher median home value is related to more groups for Baltimore and Chicago, but the reverse is true for NYC. Higher levels of racial segregation are correlated with higher amounts of stewardship groups in Chicago, but surprisingly not in other cities even though Baltimore and NYC are also highly racially segregated. Areas with higher amounts of renters are correlated with higher amounts of stewardship groups in NYC, but not other cities. Median year moved in was not correlated with number of stewardship groups across all cities. Aside from median home value at the neighborhood-level spatial model, socioeconomic data in Seattle are not correlated with number of groups, at either block group or neighborhood scales.

Environmental characteristics were retained in the models for all cities, although which factor varied across cities. In Chicago, lower impervious surface is associated with higher numbers of groups, while in Baltimore and Seattle the inverse is true. Higher proportions of open space are correlated with higher numbers of groups in Baltimore, NYC, and Seattle. NYC is the only city where presence of brownfields (contaminated sites) is positively associated with number of stewardship groups.

\section{DISCUSSION}

We provide a comparison of stewardship areas of activity for multiple cities in the U.S., expanding the work of Romolini et al.
(2013). We found some consistent patterns across cities: (1) stewardship activity areas are unequally distributed across each city and (2) organizational variables are more strongly associated with number of stewardship groups than any environmental or socioeconomic variables. All retained models include both professionalization and diversity of group focus, with relatively strong relationships to number of stewardship groups. In addition, all retained models retain some aspect of socioeconomic and environmental variables, with weaker coefficients and varying socioeconomic and environmental variables. These results have implications for how to improve civic capacity around environmental stewardship across cities and suggest that understanding the organizational landscape holds the key to change. Below, we discuss nuances of these findings, along with a consideration of city-specific patterns relative to the larger city context.

\section{Distribution of stewardship efforts in cities}

Across our four cities, we found areas of higher and lower numbers of civic stewardship groups. The unevenness of stewardship groups suggests the potential for uneven care of city spaces, varying capacity of stewardship groups, and/or localized, spatial differences in the drivers of stewardship. Inclusion of government efforts in any given city may shed light on whether civic stewardship is additive to government efforts, in place of government efforts, or both. Also, if certain stewardship groups have greater capacity than others, or if the need for care is lower in an area than elsewhere, that area may have lower numbers of stewardship groups working there. Understanding localized neighborhood histories may help elucidate these relationships. However, this relationship between number of stewardship groups working in an area and stewardship capacity is currently not well understood. Even so, given the stronger association of organizational variables with number of groups, our findings 
Table 5. Spatial lag and/or error model Beta coefficients (and $95 \%$ confidence intervals) by study area city at census block group and neighborhood scales. Starred terms are significant (alpha $=5 \%)$.

\begin{tabular}{|c|c|c|c|c|c|c|c|c|c|c|c|c|c|c|c|c|}
\hline & \multicolumn{4}{|c|}{ Baltimore } & \multicolumn{4}{|c|}{ Chicago } & \multicolumn{4}{|c|}{ New York City } & \multicolumn{4}{|c|}{ Seattle } \\
\hline & \multicolumn{2}{|c|}{$\mathrm{CBG}$} & \multicolumn{2}{|c|}{ Neighborhood } & \multicolumn{2}{|c|}{ CBG } & \multicolumn{2}{|c|}{ Neighborhood } & \multicolumn{2}{|c|}{ CBG } & \multicolumn{2}{|c|}{ Neighborhood } & \multicolumn{2}{|c|}{ CBG } & \multicolumn{2}{|c|}{ Neighborhood } \\
\hline & $\beta$ & s.e. & $\beta$ & s.e. & $\beta$ & s.e. & $\beta$ & s.e. & $\beta$ & s.e. & $\beta$ & s.e. & $\beta$ & s.e. & $\beta$ & s.e. \\
\hline Intercept & $42.737^{* 17}$ & 2.255 & $42.249^{* 1+1}$ & 3.615 & $76.817^{* * * *}$ & 4.509 & $185.195^{* 1+}$ & 20.735 & $59.029_{* * * *}^{* \cdots *}$ & 1.073 & $74.786^{* 11}$ & 8.420 & $103.493^{* 1+}$ & 8.064 & $107.417^{* * * \pi}$ & 34.977 \\
\hline Population Density & & & & & $0.000^{* * * *}$ & 0.000 & -0.044 & 0.079 & $0.000^{* * *}$ & 0.000 & -0.012 & 0.015 & & & & \\
\hline$\%$ Owner Occupied & & & & & -0.002 & 0.003 & 3.847 & 6.770 & $-0.002_{* * *}^{*}$ & 0.001 & 0.369 & 3.096 & & & & \\
\hline Median HH Income & & & & & & & & & $0.003^{* \text { *at }}$ & 0.001 & 0.004 & 0.021 & & & & \\
\hline $\begin{array}{l}\text { Median Home Value } \\
\text { \% College Education }\end{array}$ & -0.000 & 0.000 & 0.000 & 0.000 & -0.001 & 0.001 & -0.006 & 0.011 & & & & & 0.002 & 0.001 & $0.005^{* * *}$ & 0.005 \\
\hline Racial Diversity Index & & & & & $7.865^{* * *}$ & 2.890 & $2.795^{* *}$ & 1.101 & & & & & & & & \\
\hline $\begin{array}{l}\text { Median Yr. Moved In } \\
\% \text { Tree Canopy }\end{array}$ & & & & & & & & & $0.000^{* * *}$ & 0.000 & 0.000 & 0.001 & & & & \\
\hline$\%$ Impervious Surface & $-0.009_{* * * *}^{* *}$ & 0.003 & $0.017_{* * *}^{* *}$ & 0.007 & $-0.020^{* * *}$ & 0.006 & $-0.169^{*}$ & 0.101 & & & & & 0.030 & 0.016 & $0.097^{* * * *}$ & 0.045 \\
\hline$\%$ Open Space & $0.015^{* * * *}$ & 0.003 & $0.015^{* *}$ & 0.006 & & & & & $0.018_{* * * * *}^{* * *}$ & 0.002 & -0.005 & 0.021 & 0.040 & 0.015 & $0.067^{* * *}$ & 0.050 \\
\hline Has Brownfield & & & & & & & & & $0.660^{* *}$ & 0.445 & $2.691^{* *}$ & 1.719 & & & & \\
\hline Avg. Professionalization Index & $-8.364_{* * *}^{* * *}$ & 0.478 & $-10.691_{* * * * *}^{* * *}$ & 0.767 & $-10.436_{* * * *}^{* * *}$ & 1.900 & $-31.568_{* * * *}^{* * *}$ & 8.301 & $-9.332 * * * * *$ & 0.199 & $-12.867^{* * *}$ & 2.008 & $-27.085^{* * *}$ & 3.215 & $-21.201_{* * * *}^{* * *}$ & 8.233 \\
\hline Diversity of Group Focus & $10.376^{* *}$ & 4.159 & $26.933^{* * * *}$ & 6.986 & $-18.026^{* *}$ & 10.762 & $218.901^{* * *}$ & 81.590 & $-5.221^{* * *}$ & 2.146 & -4.247 & 15.298 & -2.003 & 0.155 & $-52.692^{* * *}$ & 40.106 \\
\hline$\lambda$ & \multirow{2}{*}{\multicolumn{2}{|c|}{$0.838^{* * *}$}} & \multicolumn{2}{|c|}{$0.698^{* * * .900}$} & \multirow{2}{*}{\multicolumn{2}{|c|}{$0.853^{* *+7}$}} & & & \multirow{2}{*}{\multicolumn{2}{|c|}{0.855}} & \multirow{2}{*}{\multicolumn{2}{|c|}{0.695}} & \multirow{2}{*}{\multicolumn{2}{|c|}{0.643}} & \multirow{2}{*}{\multicolumn{2}{|c|}{0.377}} \\
\hline$\rho$ & & & \multirow{3}{*}{\multicolumn{2}{|c|}{$\begin{array}{c}271 \\
0.684\end{array}$}} & & & $0.337^{*}$ & & & & & & & & & \\
\hline $\mathrm{n}$ & \multirow{2}{*}{\multicolumn{2}{|c|}{$\begin{array}{c}653 \\
0.702\end{array}$}} & & & \multirow{2}{*}{\multicolumn{2}{|c|}{$\begin{array}{l}2311 \\
0.731\end{array}$}} & 98 & & \multirow{2}{*}{\multicolumn{2}{|c|}{$\begin{array}{l}6466 \\
0.816\end{array}$}} & \multirow{2}{*}{\multicolumn{2}{|c|}{$\begin{array}{c}243 \\
0.596\end{array}$}} & \multirow{2}{*}{\multicolumn{2}{|c|}{$\begin{array}{c}477 \\
0.708\end{array}$}} & \multirow{2}{*}{\multicolumn{2}{|c|}{$\begin{array}{c}93 \\
0.417\end{array}$}} \\
\hline pseudo $\mathrm{R}^{2}$ & & & & & & & 0.705 & & & & & & & & & \\
\hline
\end{tabular}

suggest the organizational fabric of the city may reinforce this pattern of uneven stewardship distribution.

\section{Relationships with organizational variables}

By far the largest associations observed were with the two organizational variables: average professionalization index and diversity of group focus. This suggests that the organizational landscape may matter more than socioeconomic or environmental characteristics in explaining the number of groups in a given neighborhood, suggesting future work should focus on further unpacking the interorganizational aspects of stewardship groups in cities. The fewer groups in a Census block group or neighborhood, the more professionalized those groups are. This may indicate the possible presence of density dependence, whereby fewer, but more highly professionalized, groups are able to effectively steward the neighborhood's resources. It also may be that political dynamics with more professionalized organizations limit the available space for other organizations, in essence, "crowding out" other groups. An analysis of organizations over time in a neighborhood and organizational histories could parse which of these effects is occurring.

The other organizational variable we examined was the diversity of groups' focus within a neighborhood, to understand whether this diversity affected the number of groups present. The results were counterintuitive: the more stewardship groups present, the fewer topical issues were collectively addressed by stewardship groups in three of our study areas. We offer two possible explanations for this relationship. Neighborhoods with larger numbers of groups may contain fragmented groups that focus on the same mission because of competition over resources. Additionally, stewardship may inspire the development of similar groups through isomorphic behaviors (DiMaggio and Powell 1983). Baltimore is a distinctive city within our four study area cities, with the opposite pattern present. Local issues in Baltimore related to environmental governance may help explain why results differ there. Data were collected in Baltimore two years following the city's adoption of its first Sustainability Plan, and concurrent with the launch of the Federal Urban Waters Partnership in
Baltimore. These initiatives were highly publicized and may have served to encourage coordinated stewardship efforts across organizational focus areas in certain neighborhoods.

\section{Relationships with socioeconomic variables}

In addition to the size and distribution of stewardship areas of activity, we also see the relationship of number of groups' activity areas varies with social and environmental variables. But we did not find consistent patterns across our four cities, suggesting the relationship is complex and place-based. Stewardship activity may also be driven, in part, by the local regulatory and policy frameworks. Each of our four cities has a unique development history and a different distribution of green space and people across space. In addition, stewardship networks in each city developed in these places in response to local conditions. From stewardship network structures, we know not all organizations work in the same manner (see Connolly et al. 2013, 2014). Bridge organizations allow small, place-based stewardship groups to specialize but still remain connected to the remainder of the network, raising the question of how network structure affects the spatial size and distribution of groups' activity areas. Extending this analysis to analyze social networks and spatial activity areas simultaneously offers promise for understanding these interactions (see Radil et al. 2010).

In each city, different social factors were correlated with number of civic stewardship groups. Population density was only retained in the Chicago and NYC models, the denser study area cities. However, the small coefficient size suggests that the number of groups distributed across space may not be correlated with the density of people residing in an area. Home ownership was significant, with small coefficient sizes in the largest cities, NYC and Chicago, with areas with less home/housing ownership seeing larger numbers of stewardship groups in NYC and areas with more home/housing ownership seeing larger numbers of groups in Chicago. For housing variables, NYC may be an anomaly because it has lower homeownership than any other city in the United States. Home value was a factor in three cities (Baltimore, Chicago, and Seattle) for the Poisson models, with higher home 
Table 6. Comparative marginal effects (percent change) by model to number of environmental stewardship groups. All values for a one unit or category marginal change unless otherwise noted.

\begin{tabular}{|c|c|c|c|c|c|c|c|c|c|c|c|c|c|c|c|c|}
\hline & \multicolumn{4}{|c|}{ Baltimore } & \multicolumn{4}{|c|}{ Chicago } & \multicolumn{4}{|c|}{ New York City } & \multicolumn{4}{|c|}{ Seattle } \\
\hline & \multicolumn{2}{|c|}{ Poisson } & \multicolumn{2}{|c|}{ Spatial Error } & \multicolumn{2}{|c|}{ Poisson } & \multirow{2}{*}{$\begin{array}{c}\text { Spatial } \\
\text { Error } \\
\text { CBG }\end{array}$} & \multirow{2}{*}{$\begin{array}{c}\text { Spatial } \\
\text { Lag } \\
\text { Neigh }\end{array}$} & \multicolumn{2}{|c|}{ Poisson } & \multicolumn{2}{|c|}{ Spatial Error } & \multicolumn{2}{|c|}{ Poisson } & \multicolumn{2}{|c|}{ Spatial Error } \\
\hline & CBG & Neigh & CBG & Neigh & CBG & Neigh & & & CBG & Neigh & CBG & Neigh & CBG & Neigh & CBG & Neigh \\
\hline $\begin{array}{l}\text { Population } \\
\text { Density }\end{array}$ & & & & & $\begin{array}{r}0.000 \\
(-0.001- \\
0.000)\end{array}$ & $\begin{array}{r}0.014 \\
(-0.135- \\
0.162)\end{array}$ & $\begin{array}{r}0.000 \\
(0.000- \\
0.000)\end{array}$ & $\begin{array}{r}-0.004 \\
(-0.065- \\
0.057)\end{array}$ & $\begin{array}{r}0.000 \\
(0.000- \\
0.000)\end{array}$ & $\begin{array}{r}0.045 \\
(-0.027- \\
0.116)\end{array}$ & $\begin{array}{r}0.000 \\
(0.000- \\
0.000)\end{array}$ & $\begin{array}{r}-0.043 \\
(-0.097- \\
0.011)\end{array}$ & & & & \\
\hline $\begin{array}{l}\% \text { Owner } \\
\text { Occupied }\end{array}$ & & & & & $\begin{array}{r}-0.035 \\
(-0.062- \\
-0.008)\end{array}$ & $\begin{array}{r}1.708 \\
(-9.307- \\
14.065)\end{array}$ & $\begin{array}{r}-0.005 \\
(-0.013- \\
0.002)\end{array}$ & $\begin{array}{r}1.301 \\
(-3.497- \\
6.099)\end{array}$ & $\begin{array}{r}-0.076 \\
(-0.101- \\
-0.05)\end{array}$ & $\begin{array}{r}-18.087 \\
(-30.296- \\
-3.804)\end{array}$ & $\begin{array}{r}-0.008 \\
(-0.014- \\
-0.001)\end{array}$ & $\begin{array}{r}1.339 \\
(-9.899- \\
12.577)\end{array}$ & & & & \\
\hline $\begin{array}{l}\text { Median HH } \\
\text { Income }\end{array}$ & & & & & & & & & $\begin{array}{r}0.050 \\
(0.032- \\
0.069)\end{array}$ & $\begin{array}{r}0.143 \\
(0.025- \\
0.260)\end{array}$ & $\begin{array}{r}0.013 \\
(0.008- \\
0.018)\end{array}$ & $\begin{array}{r}0.015 \\
(-0.061- \\
0.091)\end{array}$ & & & & \\
\hline $\begin{array}{l}\text { Median Home } \\
\text { Value }\end{array}$ & $\begin{array}{r}0.000 \\
(0.000- \\
0.000)\end{array}$ & $\begin{array}{r}0.000 \\
(0.000- \\
0.000)\end{array}$ & $\begin{array}{r}-0.000 \\
(-0.000- \\
-0.000)\end{array}$ & $\begin{array}{r}0.000 \\
(0.000- \\
0.000)\end{array}$ & $\begin{array}{r}-0.005 \\
(-0.009- \\
0.000)\end{array}$ & $\begin{array}{r}0.009 \\
(-0.009- \\
0.028)\end{array}$ & $\begin{array}{r}-0.001 \\
(-0.003- \\
0.000)\end{array}$ & $\begin{array}{r}0.006 \\
(-0.002- \\
0.013)\end{array}$ & $\begin{array}{r}-0.003 \\
(-0.004- \\
-0.001)\end{array}$ & $\begin{array}{r}0.002 \\
(-0.004- \\
0.008)\end{array}$ & $\begin{array}{r}0.001 \\
(0.000- \\
0.001)\end{array}$ & $\begin{array}{r}0.001 \\
(-0.003- \\
0.005)\end{array}$ & $\begin{array}{r}0.006 \\
(-0.002- \\
0.015)\end{array}$ & $\begin{array}{r}0.014 \\
(-0.017- \\
0.046)\end{array}$ & $\begin{array}{r}0.005 \\
(0.003- \\
0.008)\end{array}$ & $\begin{array}{r}0.013 \\
(0.000- \\
0.027)\end{array}$ \\
\hline $\begin{array}{l}\text { \% College } \\
\text { Education } \\
\text { Racial Diversity } \\
\text { Index }\end{array}$ & & & & & $\begin{array}{r}59.936 \\
(20.899- \\
111.422)\end{array}$ & $\begin{array}{r}1.539 \\
(-0.875- \\
3.984)\end{array}$ & $\begin{array}{r}18.542 \\
(11.729- \\
25.355)\end{array}$ & $\begin{array}{r}1.530 \\
(0.514- \\
2.546)\end{array}$ & & & & & & & & \\
\hline $\begin{array}{l}\text { Median Yr. } \\
\text { Moved In } \\
\text { \% Tree Canopy } \\
\text { \% Impervious } \\
\text { Surface }\end{array}$ & $\begin{array}{r}0.171 \\
(0.084- \\
0.258)\end{array}$ & $\begin{array}{r}0.195 \\
(0.058- \\
0.331)\end{array}$ & $\begin{array}{r}-0.049 \\
(-0.087- \\
-0.011)\end{array}$ & $\begin{array}{r}0.081 \\
(0.015- \\
0.148)\end{array}$ & $\begin{array}{r}-0.064 \\
(-0.118- \\
-0.009)\end{array}$ & $\begin{array}{r}-0.107 \\
(-0.289- \\
0.075)\end{array}$ & $\begin{array}{r}-0.048 \\
(-0.062- \\
-0.034)\end{array}$ & $\begin{array}{r}-0.08 \\
(-0.158- \\
-0.002)\end{array}$ & & & & & $\begin{array}{r}0.099 \\
(-0.014- \\
0.213)\end{array}$ & $\begin{array}{r}0.271 \\
(0.015- \\
0.528)\end{array}$ & $\begin{array}{r}0.079 \\
(0.037- \\
0.121)\end{array}$ & $\begin{array}{r}0.252 \\
(0.136- \\
0.369)\end{array}$ \\
\hline $\begin{array}{l}\% \text { Open } \\
\text { Space }\end{array}$ & $\begin{array}{r}0.188 \\
(0.049- \\
0.324)\end{array}$ & $\begin{array}{r}0.128 \\
(-0.036- \\
0.289)\end{array}$ & $\begin{array}{c}0.0 .079 \\
(0.045- \\
0.113)\end{array}$ & $\begin{array}{r}0.074 \\
(0.019- \\
0.130)\end{array}$ & & & & & $\begin{array}{r}0.096 \\
(0.055- \\
0.137)\end{array}$ & $\begin{array}{r}0.103 \\
(-0.026- \\
0.231)\end{array}$ & $\begin{array}{r}0.083 \\
(0.075- \\
0.092)\end{array}$ & $\begin{array}{r}-0.017 \\
(-0.093- \\
0.058)\end{array}$ & $\begin{array}{r}0.145 \\
(-0.003- \\
0.291)\end{array}$ & $\begin{array}{r}0.188 \\
(-0.16- \\
0.528)\end{array}$ & $\begin{array}{r}0.103 \\
(0.064- \\
0.142)\end{array}$ & $\begin{array}{r}0.175 \\
(0.046- \\
0.303)\end{array}$ \\
\hline Has Brownfield & & & & & & & & & $\begin{array}{r}8.127 \\
(-2.958- \\
20.029)\end{array}$ & $\begin{array}{l}12.072 \\
(1.597- \\
23.315)\end{array}$ & $\begin{array}{r}2.983 \\
(0.973- \\
4.994)\end{array}$ & $\begin{array}{r}9.767 \\
(3.526- \\
16.008)\end{array}$ & & & & \\
\hline $\begin{array}{l}\text { Avg. Professional- } \\
\text { ization Index }\end{array}$ & $\begin{array}{r}-30.971 \\
(-41.209- \\
-18.885)\end{array}$ & $\begin{array}{r}-41.238 \\
(51.808- \\
28.277)\end{array}$ & $\begin{array}{r}-43.256 \\
(-48.106- \\
-38.407)\end{array}$ & $\begin{array}{r}-52.476 \\
(-59.855- \\
45.087)\end{array}$ & $\begin{array}{c}-19.729 \\
(-26.435- \\
-12.395)\end{array}$ & $\begin{array}{r}-29.31 \\
(-39.222- \\
-17.750)\end{array}$ & $\begin{array}{r}-24.604 \\
(-29.084- \\
-20.124)\end{array}$ & $\begin{array}{r}-28.126 \\
(-35.258- \\
-20.993)\end{array}$ & $\begin{array}{r}-33.443 \\
(-35.397- \\
-31.436)\end{array}$ & $\begin{array}{r}-34.582 \\
(-40.666- \\
-27.818)\end{array}$ & $\begin{array}{r}-42.209 \\
(-43.110- \\
-41.307)\end{array}$ & $\begin{array}{r}-46.700 \\
(-53.990- \\
-39.411)\end{array}$ & $\begin{array}{r}-44.895 \\
(-55.447- \\
-31.830)\end{array}$ & $\begin{array}{r}-41.451 \\
(-63.571- \\
-5.685)\end{array}$ & $\begin{array}{r}-70.304 \\
(-78.648- \\
-61.959)\end{array}$ & $\begin{array}{r}-55.059 \\
(-76.440- \\
-33.679)\end{array}$ \\
\hline $\begin{array}{l}\text { Diversity of } \\
\text { Group Focus }\end{array}$ & $\begin{array}{c}392.299 \\
(50.294- \\
1506.167)\end{array}$ & $\begin{array}{c}489.747 \\
(41.988- \\
2339.122)\end{array}$ & $\begin{array}{r}53.664 \\
(11.509- \\
95.819)\end{array}$ & $\begin{array}{c}132.202 \\
(64.995- \\
199.409)\end{array}$ & $\begin{array}{r}-78.124 \\
(-88.862- \\
-56.721)\end{array}$ & $\begin{array}{r}675.058 \\
(42.583- \\
4279.762)\end{array}$ & $\begin{array}{r}-42.498 \\
(-67.871- \\
17.125)\end{array}$ & $\begin{array}{c}165.179 \\
(91.252- \\
239.107)\end{array}$ & $\begin{array}{r}-44.156 \\
(-56.906- \\
-27.697)\end{array}$ & $\begin{array}{r}-48.102 \\
(-77.301- \\
17.105)\end{array}$ & $\begin{array}{c}-23.614 \\
(-33.32- \\
-13.909)\end{array}$ & $\begin{array}{r}-15.414 \\
(-70.937- \\
40.11)\end{array}$ & $\begin{array}{r}-17.285 \\
(-28.800- \\
-10.638)\end{array}$ & $\begin{array}{r}-82.154 \\
(-98.221- \\
81.620)\end{array}$ & $\begin{array}{r}-5.200 \\
(-5.603- \\
-4.796)\end{array}$ & $\begin{array}{r}-136.844 \\
(-241.000- \\
-32.688)\end{array}$ \\
\hline
\end{tabular}

values correlated with more stewardship groups in Seattle and lower home values correlated with more stewardship groups in Baltimore and Chicago, with very small coefficient sizes. However, only Seattle's correlation with higher home values at the neighborhood scale remained significant in the spatial models, suggesting a stronger relationship between housing and stewardship in Seattle than other cities. Seattle is the only city in the U.S. west in our study and has been experiencing rapidly increasing home prices in recent years.

Chicago was the only city where racial diversity of White and African American residents was retained in the models. At the Census block group scale, more segregated areas were correlated with higher numbers of stewardship groups, indicating higher numbers of groups in predominantly White or predominantly African American areas. Chicago has a long history of intentional segregation, but so do Baltimore and NYC (Massey 2008). A qualitative analysis of stewardship in multiple neighborhoods in each city could parse this result further.

Median year moved in and percent with a college education were not significant variables in any of the cities, suggesting the turnover of residents in a neighborhood is not related to the number of civic stewardship groups found there. The distribution of median year moved in had low levels of spatial correlation, in contrast to all other variables included in the analysis, which may explain this result.

\section{Relationships with environmental variables}

Given that stewardship often occurs on greenspace, we would expect to see more stewardship groups associated with more open space. This was the case in three cities (Baltimore, NYC, and Seattle). The percent open space in the average Chicago Census block group is half that of other study area cities (Table 1), which may explain the nonsignificant relationship. Percent impervious surface was retained for Baltimore, Chicago, and Seattle (Table 1). In Baltimore and Chicago, less impervious surface was correlated with more groups, while the opposite was true for Seattle. Percent tree canopy was not retained in models for any of the cities, which contrasts with Romolini et al.'s (2013) results for Baltimore and Seattle. This is likely because our model specifications differed from Romolini et al. (2013): we included additional variables and applied a count-based model form to a stepwise regression. The stewardship activities within each city may be in reaction to different conditions. Boone et al. (2010) 
found historical socioeconomic legacies to be more strongly correlated with landscape condition than current socioeconomic conditions. In a similar vein, current environmental conditions may be closer related to past care than current care and the impetus to begin stewardship in an area may be more related to past conditions than current conditions.

In NYC, the presence of a brownfield was retained in the Census block group model and significant at the neighborhood level. This suggests that neighborhoods with brownfields were more likely to have larger numbers of stewardship groups. In NYC, there are prominent brownfield sites that have acted as sources of redevelopment and resulted in increased civic activity to oppose or constrain redevelopment (Pearsall 2013). Previous research has identified that stewardship groups may be acting to conserve some areas while restoring others (Romolini et al. 2013). Different groups may be engaged in different activities, which could lead to larger numbers of groups operating in neighborhoods containing both green spaces and brownfield sites.

\section{Study limitations and opportunities for future research}

These varying relationships across cities raise further questions about whether stewardship groups differ across cities in their mission and participants. Local stewardship groups often include residents of a particular place. At the same time, a known limitation of Census data is that it focuses on where people reside, not necessarily where people spend their time during the day (Goodchild and Janelle 1984). Commercial areas, parks, and many other public spaces may be stewarded, not because people reside here, but because they are places of value to city dwellers.

One limitation of this study is unavoidable when using polygons in spatial analysis: the Modifiable Areal Unit Problem (MAUP; Openshaw 1984). Our results highlight that some relationships remain stable across scales, but others shift as data are aggregated to a higher scale. Another limitation to our approach is that these activity areas are a subset of the population of environmental stewardship groups working in a given city. In NYC and Seattle, we found the groups sampled to be spatially representative to the larger sampling frame based on office location. For Baltimore and Chicago, we currently lack complete spatial datasets of the sampling frame's office locations (Baltimore) or used a combined approach (sampling frame and open survey, Chicago), so we cannot undertake this same analysis and cannot assume the mapped areas of activity for groups represent the distribution of stewardship groups' activity areas in these two cities.

Lacking consistent patterns for socioeconomic and environmental context across our cities requires us to consider additional methods and variables for investigating relationships between stewardship groups and the environment they steward. In this paper, we have focused on number of stewardship groups as the dependent variable, because of its relative simplicity. Not all stewardship groups are focused on trees or brownfields, for which we had consistent data across cities. They also can focus on community gardens, vacant lots, ecological restoration, water quality, or sustainable systems, for example. However, is number of groups the appropriate variable to examine? The number of stewardship groups may also be correlated with the collective efficacy, or stewardship capacity, of groups in a given area. How to effectively define stewardship capacity is an important research goal, necessary to fully understand the effect of a group on the resource being stewarded. Bennett et al. (2018) conceptualize stewardship capacity as a combination of assets, i.e., cultural, social, financial, physical, human, and institutional; future work could incorporate such measures into similar neighborhood-level analyses.

\section{CONCLUSION}

This study was designed to better understand the geographies of civic environmental stewardship groups, given the context of complex spatial heterogeneity in several cities in the United States. We found similar organizational relationships but different socioeconomic and environment patterns in each of the four cities. Across cities, a similarity of group focus and lower professionalization were associated with higher numbers of groups in a neighborhood. One exception was Baltimore, where a higher diversity of group focus was associated with a higher number of groups. Our fundamental conclusion is that overall, the number of stewardship groups correlates with social and environmental aspects of each city at a local level, but the organizational characteristics examined have the strongest relationship to number of groups working in a neighborhood. We find clear relationships between environmental stewardship and urban geography; further work is needed to unpack the organizational landscape and how it affects the proliferation of groups in a given neighborhood. Finally, this study focused on the number of stewardship groups; critical relationships and associations may emerge when considering stewardship capacity and more localized neighborhood histories of stewardship as related to urban redevelopment and land use.

\section{Responses to this article can be read online at: http://www.ecologyandsociety.org/issues/responses. php/10924}

\begin{abstract}
Acknowledgments:
We thank the Edna Bailey Sussman Fund, the Libby Fund Enhancement Award and the Pruser Fellowship from Clark University, for providing funding for this research. This work was supported by the National Socio-Environmental Synthesis Center (SESYNC) under funding received from the National Science Foundation DBI-105287.
\end{abstract}

\section{LITERATURE CITED}

Andersson, E., S. Barthel, and K. Ahrné. 2007. Measuring socialecological dynamics behind the generation of ecosystem services. Ecological Applications 17(5):1267-1278. https://doi. org/10.1890/06-1116.1

Andersson, E., S. Barthel, S. Borgström, J. Colding, T. Elmqvist, C. Folke, and A. Gren. 2014. Reconnecting cities to the biosphere: stewardship of green infrastructure and urban ecosystem services. Ambio 43(4):445-453. https://doi.org/10.1007/s13280-014-0506y

Anselin, L. 2005. Exploring spatial data with GeoDa ${ }^{T M}$ : a workbook. Center for Spatially Integrated Social Science, Santa Barbara, California, USA. [online] URL: http://www.csiss.org/ clearinghouse/GeoDa/geodaworkbook.pdf 
Baddeley, A., and R. Turner. 2005. Spatstat: an R package for analyzing spatial point patterns. Journal of Statistical Software 12(6):1-42. https://doi.org/10.18637/jss.v012.i06

Baek, S., S. Raja, J. Park, L. H. Epstein, L. Yin, and J. N. Roemmich. 2015. Park design and children's active play: a microscale spatial analysis of intensity of play in Olmsted's Delaware Park. Environment and Planning B: Planning and Design 42(6):1079-1097. https://doi.org/10.1177/0265813515599515

Bennett, N. J., T. S. Whitty, E. Finkbeiner, J. Pittman, H. Bassett, S. Gelcich, and E. H. Allison. 2018. Environmental stewardship: a conceptual review and analytical framework. Environmental Management 61(4):597-614. http://dx.doi.org/10.1007/s00267-017-0993-2

Bivand, R., and G. Piras. 2015. Comparing implementations of estimation methods for spatial econometrics. Journal of Statistical Software 63(18):1-36. https://doi.org/10.18637/jss. $\underline{\mathrm{v} 063.118}$

Boone, C. G., G. L. Buckley, J. M. Grove, and C. Sister. 2009. Parks and people: an environmental justice inquiry in Baltimore, Maryland. Annals of the Association of American Geographers 99 (4):767-787. https://doi.org/10.1080/00045600903102949

Boone, C. G., M. L. Cadenasso, J. M. Grove, K. Schwarz, and G. L. Buckley. 2010. Landscape, vegetation characteristics, and group identity in an urban and suburban watershed: why the 60s matter. Urban Ecosystems 13:255-271. https://doi.org/10.1007/ $\underline{\text { s11252-009-0118-7 }}$

Borgström, S. T., T. Elmqvist, P. Angelstam, and C. AlfsenNorodom. 2006. Scale mismatches in management of urban landscapes. Ecology and Society 11(2):16. https://doi.org/10.5751/ ES-01819-110216

Campbell, L. K., L. F. Landau, M. L. Johnson, and E. S. Svendsen. In press. Civic stewardship of urban ecosystems: forms of community engagement with landscapes and places. Pages 208-224 in M. Chatterjee and E. Svyatets, editors. Environmental issues and policy: exploring past, present and future socioecological relations. Cognella, San Diego, California, USA.

Chicago Regional Biodiversity Council. 1999. Biodiversity recovery plan. Northeastern Illinois Planning Commission, Northeastern Indiana Regional Coordinating Council, Chicago, Illinois, USA.

City of Baltimore. 2014. Parks dataset. Open Baltimore. City of Baltimore, Maryland, USA. [online] URL: https://data. baltimorecity.gov/Culture-Arts/Parks/3r8a-uawz

City of Chicago. 2016. Parks - Shapefiles dataset. Chicago Data Portal. City of Chicago, Illinois, USA. [online] URL: https://data. cityofchicago.org/Parks-Recreation/Parks-Shapefiles-deprecatedNovember-2016-/5msb-wbxn

City of Seattle. 2014. City of Seattle Parks. Seattle Open Data Program. City of Seattle, Washington, USA.

Connolly, J. J., E. S. Svendsen, D. R. Fisher, and L. K. Campbell. 2013. Organizing urban ecosystem services through environmental stewardship governance in New York City. Landscape and Urban Planning 109(1):76-84. https://doi.org/10.1016/j.landurbplan.2012.07.001
Connolly, J. J. T., E. S. Svendsen, D. R. Fisher, and L. K. Campbell. 2014. Networked governance and the management of ecosystem services: the case of urban environmental stewardship in New York City. Ecosystem Services 10:187-194 https://doi.org/10.1016/ j.ecoser.2014.08.005

Costa, D. L., and M. E. Kahn. 2003. Understanding the American decline in social capital, 1952-1998. Kyklos 56(1):17-46. https:// doi.org/10.1111/1467-6435.00208

DiMaggio, P., and W. W. Powell. 1983. The iron cage revisited: institutional isomorphism and collective rationality in organizational fields. American Sociological Review 48 (2):147-160. https://doi.org/10.1016/S0742-3322(00)17011-1

Engbers, T. A. 2016. Building community? The characteristics of America's most civic cities. Journal of Public Affairs 16(1):50-56. https://doi.org/10.1002/pa.1567

Environmental Protection Agency (EPA). 2015. Brownfields (ACRES) spatial dataset. Geospatial Data Download Service. EPA, Washington, D.C., USA.

Ernstson, H., S. Barthel, E. Andersson, and S. Borgström. 2010. Scale-crossing brokers and network governance of urban ecosystem services: the case of Stockholm. Ecology and Society 15(4):28. https://doi.org/10.5751/ES-03692-150428

Ernstson, H., S. Sörlin, and T. Elmqvist. 2008. Social movements and ecosystem services - the role of social network structure in protecting and managing urban green areas in Stockholm. Ecology and Society 13(2):39. https://doi.org/10.5751/es-02589-130239

ESRI. 2012. ArcGIS Desktop: Release 10.1. Environmental Systems Research Institute, Redlands, California, USA.

Fisher, D. R., L. K. Campbell, and E. S. Svendsen. 2012. The organisational structure of urban environmental stewardship. Environmental Politics 21(1):26-48. https://doi.org/10.1080/09644016.2011.643367

Gerrish, E., and S. L. Watkins. 2018. The relationship between urban forests and income: a meta-analysis. Landscape and Urban Planning 170:293-308. https://doi.org/10.1016/j.landurbplan.2017.09.005

Goodchild, M. F., and D. G. Janelle. 1984. The city around the clock: space-time patterns of urban ecological structure. Environment and Planning A 16(6):807-820. https://doi. org/10.1068/a160807

Hager, M. A., S. Wilson, T. H. Pollak, and P. M. Rooney. 2003. Response rates for mail surveys of nonprofit organizations: a review and empirical test. Nonprofit and Voluntary Sector Quarterly 32(2):252-267. https://doi.org/10.1177/0899764003032002005

Hannan, M. T., and J. Freeman. 1989. Organizational ecology. Harvard University Press, Cambridge, Massachusetts, USA https://doi.org/10.2307/j.ctvjz813k

Heynen, N. C. 2003. The scalar production of injustice within the urban forest. Antipode 35(5):980-998. https://doi.org/10.1111/ j.1467-8330.2003.00367.x

Hwang, H., and W. W. Powell. 2009. The rationalization of charity: the influences of professionalism in the nonprofit sector. Administrative Science Quarterly 54(2):268-298. https://doi. org/10.2189/asqu.2009.54.2.268 
Illenberger, J., K. Nagel, and G. Flötteröd. 2013. The role of spatial interaction in social networks. Networks and Spatial Economics 13(3):255-282. https://doi.org/10.1007/s11067-012-9180-4

Kremer, P., Z. A. Hamstead, and T. McPhearson. 2013. A socialecological assessment of vacant lots in New York City. Landscape and Urban Planning 120:218-233. https://doi.org/10.1016/j. landurbplan.2013.05.003

Landry, S. M., and J. Chakraborty. 2009. Street trees and equity: evaluating the spatial distribution of an urban amenity. Environment and Planning A 41(11):2651-2670. https://doi. org/10.1068/a41236

Locke, D. H., K. L. King, E. S. Svendsen, L. K. Campbell, C. Small, N. F. Sonti, D. R. Fisher, and J. W. T. Lu. 2014. Urban environmental stewardship and changes in vegetative cover and building footprint in New York City neighborhoods (2000-2010). Journal of Environmental Studies and Sciences 4(3):250-262. https://doi.org/10.1007/s13412-014-0176-x

Locke, D. H., and T. McPhearson. 2018. Urban areas do provide ecosystem services. Frontiers in Ecology and the Environment 16 (4):203-205. https://doi.org/10.1002/fee.1796

Mallach, A. 2018. The divided city: poverty and prosperity in urban America. Island Press, Washington, D.C., USA. https://doi. org/10.5822/978-1-61091-782-7

Marquardt, D. W. 1970. Generalized inverses, ridge regression, biased linear estimation, and nonlinear estimation. Technometrics 12:591-612. https://doi.org/10.2307/1267205

Massey, D. S. 2008. Origins of economic disparities: the historical role of housing segregation. Pages 39-80 in J. H. Carr and N. K. Kutty, editors. Segregation: the rising costs for America. Routledge, New York, New York, USA.

Meyer, M., and C. Hyde. 2004. Too much of a "good" thing? Insular neighborhood associations, nonreciprocal civility, and the promotion of civic health. Nonprofit and Voluntary Sector Quarterly 33(3_suppl):77S-96S. https://doi.org/10.1177/0899764$\underline{004265432}$

Moskal, L. M., D. M. Styers, and M. Halabisky. 2011. Monitoring urban tree cover using object-based image analysis and public domain remotely sensed data. Remote Sensing 3(10):2243-2262. https://doi.org/10.3390/rs3102243

New York City. 2015. Open Space (Parks). NYC OpenData. City of New York, New York, USA. [online] URL: https://data. cityofnewyork.us/Recreation/Open-Space-Parks-/g84h-jbjm

Nicholls, W. 2009. Place, networks, space: theorising the geographies of social movements. Transactions of the Institute of British Geographers 34(1):78-93. https://doi.org/10.1111/ j.1475-5661.2009.00331.x

O'Neil-Dunne, J. P. M. 2009. A report on the City of Baltimore's existing and possible tree canopy. The Spatial Analysis Lab at the University of Vermont's Rubenstein School of the Environment and Natural Resources, Burlington, Vermont, USA. [online] URL: http://www.fs.fed.us/nrs/utc/reports/UTC Report BACI 2007. pdf

O'Neil-Dunne, J. P. M. 2012. A report on the City of New York's existing and possible tree canopy 2010. The Spatial Analysis Lab at the University of Vermont's Rubenstein School of the Environment and Natural Resources, Burlington, Vermont, USA. [online] URL: https://www.fs.fed.us/nrs/utc/reports/ UTC NYC_Report_2010.pdf

O'Neil-Dunne, J. P. M. 2015. Tree canopy report: Cook County, $I L$. The Spatial Analysis Lab at the University of Vermont's Rubenstein School of the Environment and Natural Resources, Burlington, Vermont, USA. [online] URL: https://www. mortonarb.org/files/Tree $\% 20$ Canopy $\% 20$ Report $\% 20$ Cook $\% 20$ County. pdf

Openshaw, S. 1984. The modifiable area unit problem: concepts and techniques in modern geography. Geobooks, Norwich, UK.

Pearsall, H. 2013. Superfund me: a study of resistance to gentrification in New York City. Urban Studies 50(11):2293-2310. https://doi.org/10.1177/0042098013478236

R Core Team. 2017. R: A language and environment for statistical computing. R Foundation for Statistical Computing, Vienna, Austria. [online] URL. https://www.R-project.org/

Radil, S. M., C. Flint, and G. E. Tita. 2010. Spatializing social networks: using social network analysis to investigate geographies of gang rivalry, territoriality, and violence in Los Angeles. Annals of the Association of American Geographers 100(2):307-326. https://doi.org/10.1080/00045600903550428

Reibel, M. 2007. Geographic information systems and spatial data processing in demography: a review. Population Resources Policy Review 26:601-618. https://doi.org/10.1007/s11113-007-9046-5

Romolini, M., R. P. Bixler, and J. M. Grove. 2016. A socialecological framework for urban stewardship network research to promote sustainable and resilient cities. Sustainability 8(9):956. https://doi.org/10.3390/su8090956

Romolini, M., J. M. Grove, and D. H. Locke. 2013. Assessing and comparing relationships between urban environmental stewardship networks and land cover in Baltimore and Seattle. Landscape and Urban Planning 120:190-207. https://doi. org/10.1016/j.landurbplan.2013.08.008

Rotolo, T., and J. Wilson. 2014. Social heterogeneity and volunteering in U.S. cities. Sociological Forum 29(2):429-452. https://doi.org/10.1111/socf.12091

Rotolo, T., J. Wilson, and M. E. Hughes. 2010. Homeownership and volunteering: an alternative approach to studying social inequality and civic engagement. Sociological Forum 25:570-587. https://doi.org/10.1111/j.1573-7861.2010.01196.x

Sampson, R. J. 2008. "After-school" Chicago: space and the city. Urban Geography 29(2):127-137. https://doi.org/10.2747/0272-3$\underline{638.29 .2 .127}$

Sampson, R. J. 2017. Urban sustainability in an age of enduring inequalities: advancing theory and ecometrics for the 21 st-century city. Proceedings of the National Academy of Sciences 114 (34):8957-8962. https://doi.org/10.1073/pnas.1614433114

Sanderson, E. W., J. Walston, and J. G. Robinson. 2018. From bottleneck to breakthrough: urbanization and the future of biodiversity conservation. BioScience 68(6):412-426. https://doi. org/10.1093/biosci/biy039 
Schwarz, K., M. Fragkias, and C. G. Boone, W. Zhou, M. McHale, J. M. Grove, J. O'Neil-Dunne, J. P. McFadden, G. L. Buckley, D. Childers, L. Ogden, S. Pincetl, D. Pataki, A. Whitmer, and M. L. Cadenasso. 2015. Trees grow on money: urban tree canopy cover and environmental justice. PLoS ONE 10(4):e0122051. https:// doi.org/10.1371/journal.pone.0122051

Short, J. R., and M. Mussman. 2014. Population change in U.S. cities: estimating and explaining the extent of decline and level of resurgence. Professional Geographer 66(1):112-123. https://doi. org/10.1080/00330124.2013.765297

Staggenborg, S. 1986. Coalition work in the pro-choice movement: organizational and environmental opportunities and obstacles. Social Problems 33:374-389. https://doi.org/10.2307/800657

Stoll, M. A. 2001. Race, neighborhood poverty and participation in voluntary associations. Sociological Forum 16(3):529-557.

Svendsen, E., and L. K. Campbell. 2008. Urban ecological stewardship: understanding the structure, function and network of community-based urban land management. Cities and the Environment (CATE) 1(1):1-4.

Svendsen, E. S., L. K. Campbell, D. R. Fisher, J. J. T. Connolly, M. L. Johnson, N. F. Sonti, D. H. Locke, L. M. Westphal, C. L. Fisher, J. M. Grove, M. Romolini, D. J. Blahna, and K. L. Wolf. 2016. Stewardship mapping and assessment project: a framework for understanding community-based environmental stewardship. General Technical Report NRS-156. U.S. Forest Service, Northern Research Station, Newtown Square, Pennsylvania, USA. https://doi.org/10.2737/NRS-GTR-156

Tavares, A. F., and J. B. Carr. 2013. So close, yet so far away? The effects of city size, density and growth on local civic participation. Journal of Urban Affairs 35(3):283-302. https://doi.org/10.1111/ j.1467-9906.2012.00638.x

Tolsma, J., T. van der Meer, and M. Gesthuizen. 2009. The impact of neighbourhood and municipality characteristics on social cohesion in the Netherlands. Acta Politica 44(3):286-313. https:// doi.org/10.1057/ap.2009.6

Troy, A., A. Nunery, and J. M. Grove. 2016. The relationship between residential yard management and neighborhood crime: an analysis from Baltimore City and County. Landscape and Urban Planning 147:78-87. https://doi.org/10.1016/j. landurbplan.2015.11.004

Venables, W. N., and B. D. Ripley. 2002. Modern applied statistics with $S$. Fourth edition. Springer, New York, New York, USA. https://doi.org/10.1007/978-0-387-21706-2

Walker, G. 2009. Beyond distribution and proximity: exploring the multiple spatialities of environmental justice. Antipode 41 (4):614-636. https://doi.org/10.1111/j.1467-8330.2009.00691.x

Watkins, S. L., and E. Gerrish. 2018. The relationship between urban forests and race: a meta-analysis. Journal of Environmental Management 209:152-168. https://doi.org/10.1016/j.jenvman.2017.12.021

Westphal, L. M., A. Y. Davis, C. Copp, L. M. Ross, M. J. Bouman, C. L. Fisher, and M. K. Johnston 2014. Characteristics of stewardship in the Chicago Wilderness Region. Cities and the Environment (CATE) 7(1).
Wilson, J. 2012. Volunteerism research: a review essay. Nonprofit \& Voluntary Sector Quarterly 41:176-212. https://doi. org/10.1177/0899764011434558

Wilson, W. H. 1994. The city beautiful movement. Johns Hopkins University Press, Baltimore, Maryland, USA.

Wolf, K. L., D. J. Blahna, W. Brinkley, and M. Romolini. 2013. Environmental stewardship footprint research: linking human agency and ecosystem health in the Puget Sound region. Urban Ecosystems 16(1):13-32. https://doi.org/10.1007/s11252-011-0175-6 


\section{Appendix 1}

New York City

L with 10,000 simulations

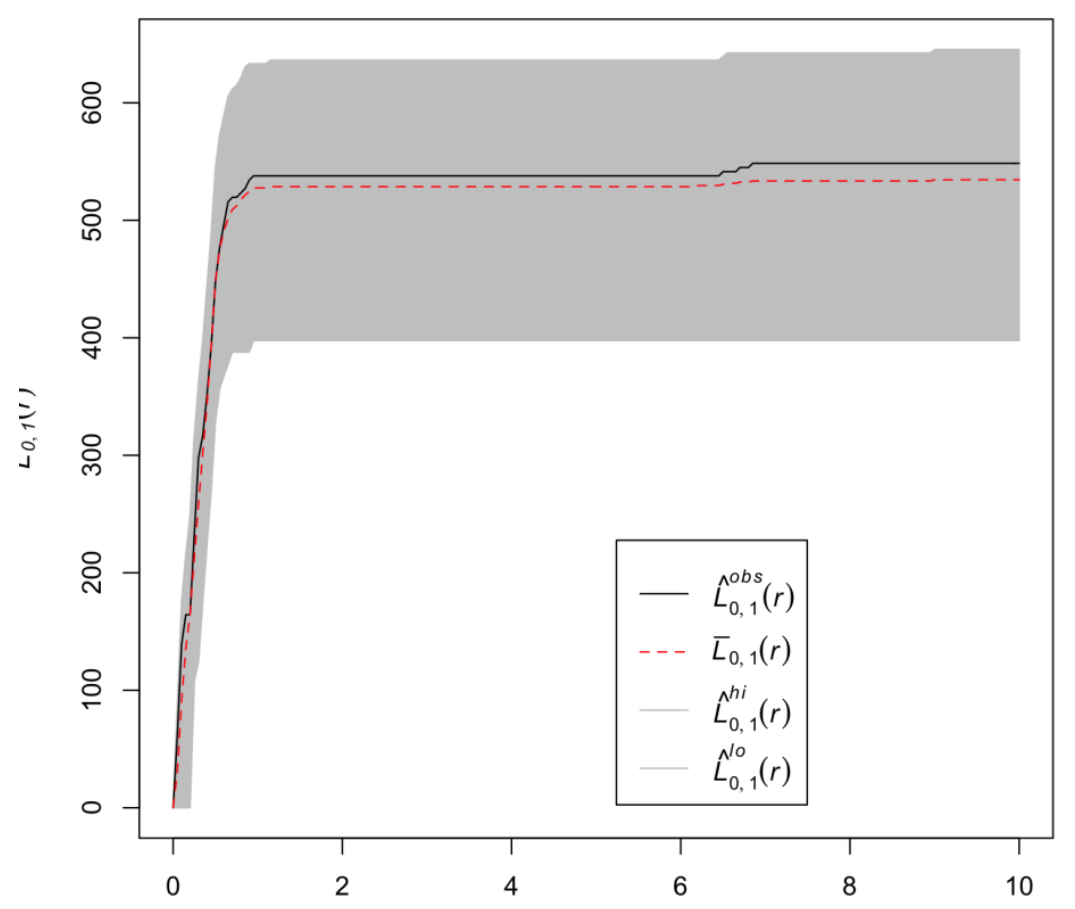

Seattle

L with 10,000 simulations

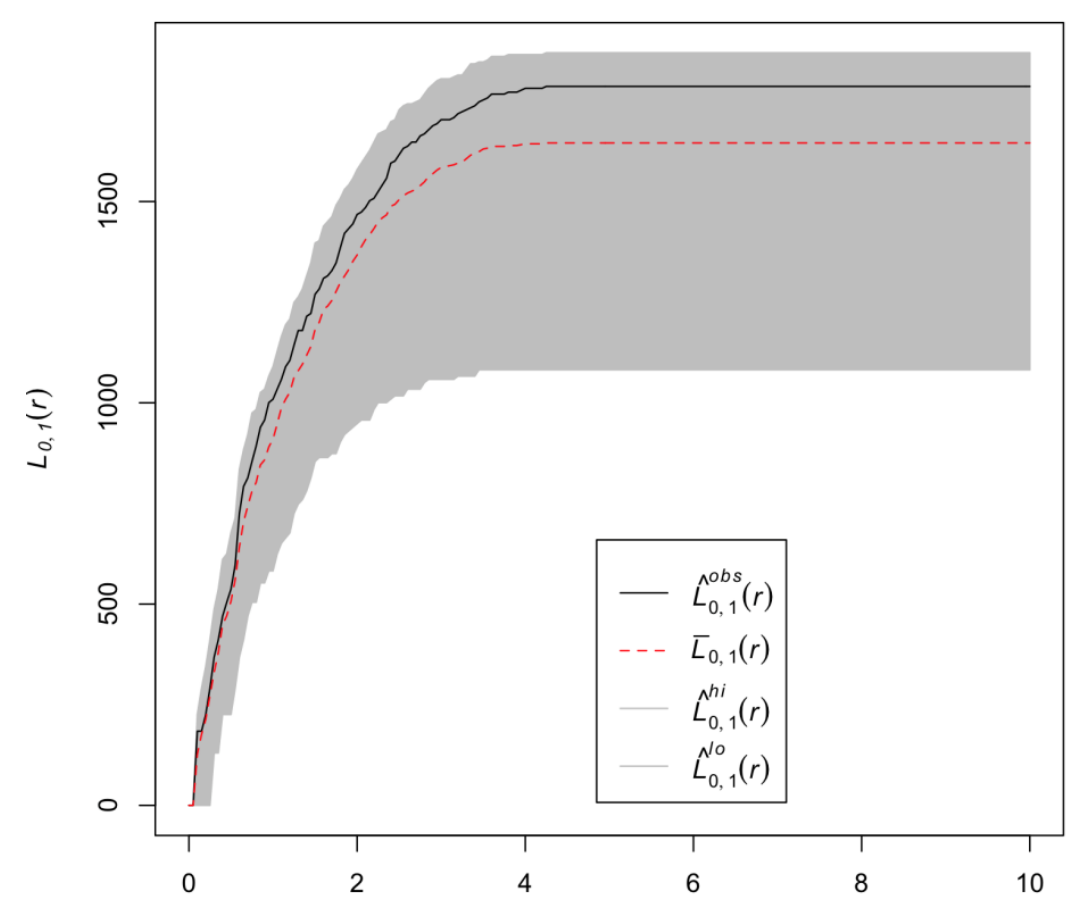

